Bangladesh J. Bot. 48(2): 321-328, 2019 (June)

\title{
MICROBIOLOGICAL QUALITY ASSESSMENT OF HERBAL MEDICINAL PRODUCTS AND ANTIBIOTIC RESISTANCE PROFILE OF BACTERIA
}

\author{
Md ShorifujJaman and Md Shahinur KabiR* \\ Department of Botany, Faculty of Biological Sciences, Jahangirnagar University, \\ Savar, Dhaka 1342, Bangladesh \\ Keywords: Microbiological quality, Herbal, Antibiotic resistance, Escherichia coli, \\ Staphylococcus aureus
}

\begin{abstract}
The microbiological quality of some herbal medicinal products available in Dhaka, Bangladesh was evaluated. In the studied samples, the total aerobic bacterial count (TABC) varied from $6.20 \times 10^{2}$ to $2.97 \times$ $10^{5} \mathrm{cfu} / \mathrm{ml}$, total yeast and mold count ranged from 0 to $1.80 \times 10^{4} \mathrm{cfu} / \mathrm{ml}$, total coliform count varied from 0 to $2.80 \times 10^{3} \mathrm{cfu} / \mathrm{ml}$ and total staphylococcal count (TSC) ranged from 0 to $2.30 \times 10^{4} \mathrm{cfu} / \mathrm{ml}$. A strong positive correlation $(\mathrm{r}=0.849)$ was observed between TABC and TSC. Out of 24 herbal medicinal samples examined, $5(20.83 \%)$ did not comply with the microbiological criteria set by internationally recognized organizations. The study revealed that $100 \%$ of the Escherichia coli isolates were resistant to amoxicillin and penicillin G, $85.71 \%$ were resistant to nitrofurantoin and $71.43 \%$ were resistant to ceftriaxone and cefuroxime: and $57.14 \%$ were resistant to erythromycin. Among the Staphylococcus aureus isolates tested, $100 \%$ were resistant to amoxicillin, nalidixic acid and Penicillin G; whereas $33.33 \%$ showed resistance to cefuroxime.
\end{abstract}

\section{Introduction}

Herbal medicine is a plant-derived material or preparation with therapeutic or other human health benefits which contains either raw or processed ingredients from one or more plants (WHO 2000). Herbal medicines are also referred to as herbal remedies, herbal products, herbal medicinal products, phytotherapeutic agents, phytopharmaceuticals and phytomedicines (Barnes et al. 2007). Many people throughout the world, particularly from the developing countries, rely on herbal medicinal products to get relief from different diseases or health related problems. Herbal medicines have gained its popularity among the people of different ages because of presumed low side-effect, low cost and a high level of acceptance by patients (Wilt et al. 2000). With the increasing use of herbal medicinal products and the worldwide expansion of the herbal medicinal market, quality and safety have become the concern for both health authorities and the public in many countries.

Microbial contamination of herbal preparations with microorganisms irrespective of being pathogenic or nonpathogenic can bring changes in their physical, chemical and organoleptic properties. The presence of certain microorganisms in non-sterile herbal products may adversely affect the therapeutic potential of the product or even make the product harmful for the patient. Several studies (Ali et al. 2005, Govender et al. 2006, Okunlola et al. 2007, Khurana et al. 2011, Onyambu et al. 2013) have showed that in some developing countries herbal medicinal products are released to the market without adequate supervision. Hence, high microbial contamination may occur in these products (Ali et al. 2005, Sharafati-chaleshtori et al. 2011). Studies have reported contamination of herbal products with disease causing organisms such as Bacillus spp., Salmonella spp. and Staphylococcus aureus (Govender et al. 2006).

\footnotetext{
*Author for correspondence: <shahin@juniv.edu>.
} 
Antibiotic resistance is one of the most pressing public health problems (WHO 2014). Almost every type of bacteria is becoming stronger and less sensitive to antibiotic treatment when it is really needed. These antibiotic-resistant bacteria can quickly spread to family members, coworkers and schoolmates threatening the whole community with a new strain of infectious disease that is more difficult to cure and more expensive to treat. Further exacerbating the problem, pharmaceutical companies are developing fewer new antibiotics to replace those that are no longer effective (Silbergeld et al. 2008).

In Bangladesh, many people rely upon the herbal medicinal products ignoring the microbial hazards associated with them. To fulfill the growing demand, several registered and unregistered local companies are producing herbal medicines. Some studies have been done on the chemical quality of herbal medicinal products manufactured in Bangladesh but study on the microbiological quality and antibiotic resistance profile of the bacteria isolated from those products is limited (Shoeb et al. 2011). Presence of unacceptable level of microbes in oral liquid herbal medicinal products can be harmful for the consumer particularly for the children, elderly people and the immunocompromised persons. Thus, the present study was conducted to evaluate the microbial quality of oral liquid herbal medicinal products available in Bangladesh and to determine the antibiotic resistance profile of some isolated bacteria.

\section{Materials and Methods}

A total of 24 liquid herbal medicinal products representing 8 different brands were randomly collected from different drug stores located in Dhaka, Bangladesh. The samples were transported to the Department of Botany, Jahangirnagar University for microbiological analysis. The volume, date of manufacture, date of expiry and therapeutic indications were recorded. The density of the samples was determined according to Okunlola et al. (2007). The microbiological analysis of samples were done before the expiry date. One milliliter sample was withdrawn aseptically and transferred to $9 \mathrm{ml}$ sterile normal saline $(0.9 \%)$ for serial dilution (Mugoyela and Mwambete 2010). One hundred microlitre of original or ten-folds serially diluted samples were spread aseptically onto Petri plates containing different medium. Nutrient agar (NA), MacConkey agar and mannitol salt agar (MSA) media (Hi-Media) were used for the enumeration of total aerobic bacteria, total coliform and total Staphylococci, respectively. The plates were incubated at $37^{\circ} \mathrm{C}$ for $24 \mathrm{hrs}$. Characteristic colonies that formed onto the MacConkey agar and MSA plates were counted and average number of colony forming unit (cfu) was determined for each $\mathrm{ml}$ of the liquid herbal samples. The mesophilic spore forming bacteria was enumerated according to Lopamudra and Kuila (2005). For the enumeration of total yeast and mold, potato dextrose agar (PDA) medium supplemented with antibiotic was used. Inoculated PDA plates were kept at room temperature for 5 days for the growth of yeast and mold. Colonies developed on the plates were counted and expressed as colony forming unit (cfu) / $\mathrm{ml}$ after proper calculation.

Bacterial colonies developed on the culture plates were randomly picked for pure culture. The purified bacterial isolates were identified based on the colony morphology, growth on selective media, Gram staining, spore staining, catalase test, coagulase test, indole production, methyl red (MR) test, Voges-Proskauer (VP) test, sugar fermentation tests, mannitol fermentation test, gas production, $\beta$ hemolytic activity and novobiocin susceptibility (Finegold and Martin 1982, Cappuccino and Sherman 1996, Brooks et al. 2007).

Susceptibility of the E. coli and $S$. aureus isolated from herbal sample to antibiotics was determined in vitro by employing disc diffusion method (Bauer et al. 1966). Susceptibility of the isolates was tested against 10 antibiotics. A portion of E. coli or S. aureus colony was inoculated into the Mueller Hinton ( $\mathrm{MH}$ ) broth and incubated at $37^{\circ} \mathrm{C}$ to obtain a young culture. A sterile 
cotton swab was dipped in the suspension and streaked over the surface of MH agar medium. Antibiotic impregnated discs were then aseptically placed on the surface of the $\mathrm{MH}$ agar medium with the help of a pair of sterile forceps. The plates were incubated at $37^{\circ} \mathrm{C}$. After $24 \mathrm{hrs}$ incubation, the plates were examined and the diameter of the zones of inhibition was measured to the nearest whole millimeter. The $S$. aureus and E. coli isolates were classified as sensitive (S) and resistant (R) to a particular antibiotic based on the diameter of zone of inhibition (CLSI 2006).

\section{Results and Discussion}

Microbial load in the herbal medicinal samples was determined and the data were compared with the standards mentioned in the British Pharmacopoeia (2004) and WHO (2007). On the label of all the samples, the date of manufacture, date of expiry, volume and therapeutic indications were clearly mentioned (Table 1).

Table 1. Basic information about the studied samples.

\begin{tabular}{|c|c|c|c|c|c|c|}
\hline $\begin{array}{l}\text { Sample } \\
\text { code }\end{array}$ & $\begin{array}{l}\text { Volume } \\
(\mathrm{ml})\end{array}$ & Colour & $\begin{array}{c}\text { Density } \\
(\mathrm{g} / \mathrm{ml})\end{array}$ & DOM & DOE & $\begin{array}{l}\text { Therapeutic } \\
\text { indication }\end{array}$ \\
\hline AS1 & 450 & Dark brown & 1.00 & Oct 2014 & Oct 2016 & \multirow{3}{*}{$\begin{array}{l}\text { Arthritis, epilepsy, insanity, } \\
\text { insomnia, leanness, memory } \\
\text { disorder, nervous debility and } \\
\text { syncope. }\end{array}$} \\
\hline AS2 & 450 & $"$ & 1.13 & Jun 2015 & Jun 2017 & \\
\hline AS3 & 450 & " & 1.00 & Jan 2016 & Jan 2018 & \\
\hline BA1 & 450 & $"$ & 1.00 & Dec 2014 & Dec 2016 & \multirow{3}{*}{$\begin{array}{l}\text { Anorexia, general debility, loss of } \\
\text { weight, malnutrition and } \\
\text { rheumatism. }\end{array}$} \\
\hline BA2 & 450 & $"$ & 1.03 & Jul 2015 & Jul 2017 & \\
\hline BA3 & 450 & $"$ & 1.10 & Nov 2015 & Nov 2017 & \\
\hline CA1 & 100 & $"$ & 0.90 & Dec 2014 & Dec 2016 & \multirow{3}{*}{$\begin{array}{l}\text { Abdominal pain, anorexia, } \\
\text { constipation, digestive and } \\
\text { carminative to correct hyperacidity, } \\
\text { flatulence, indigestion, etc. }\end{array}$} \\
\hline CA2 & 100 & $"$ & 1.30 & Jan 2015 & Jan 2017 & \\
\hline CA3 & 100 & " & 0.90 & Jan 2016 & Jan 2018 & \\
\hline EN1 & 200 & $"$ & 1.07 & Jun 2015 & May 2017 & \multirow{3}{*}{$\begin{array}{l}\text { Debility, strength and energy } \\
\text { booster, tonic for asthmatic patient, } \\
\text { etc. }\end{array}$} \\
\hline $\mathrm{EN} 2$ & 100 & $"$ & 1.30 & Feb 2015 & Jan 2017 & \\
\hline EN3 & 200 & " & 1.13 & Sep 2015 & Aug 2017 & \\
\hline HE1 & 100 & Off white & 1.00 & Mar 2015 & Mar 2017 & \multirow{3}{*}{$\begin{array}{l}\text { Abdominal pain and symptoms } \\
\text { during teething, diarrhea, flatulence, } \\
\text { indigestion. }\end{array}$} \\
\hline HE2 & 100 & $"$ & 0.93 & Jul 2015 & Jul 2017 & \\
\hline HE3 & 100 & " & 1.00 & Aug 2015 & Aug 2017 & \\
\hline NA1 & 100 & Light orange & 0.93 & Dec 2013 & Dec 2015 & \multirow{3}{*}{$\begin{array}{l}\text { Anemia, deficiency of vitamin } \\
\mathrm{C} \text {, fatigue, general weakness, } \\
\text { nervous debility, weakness of } \\
\text { stomach and liver. }\end{array}$} \\
\hline NA2 & 100 & " & 0.93 & Aug 2014 & Aug 2016 & \\
\hline NA3 & 100 & $"$ & 1.00 & Jun 2015 & Jun 2017 & \\
\hline SA1 & 100 & Dark brown & 1.27 & Aug 2015 & Aug 2018 & \multirow{3}{*}{$\begin{array}{l}\text { Constipation, depression, } \\
\text { indigestion, nose bleeding, skin } \\
\text { diseases, etc. }\end{array}$} \\
\hline $\mathrm{SA} 2$ & 100 & $"$ & 1.00 & Aug 2015 & Aug 2018 & \\
\hline SA3 & 100 & " & 1.20 & Feb 2016 & Feb 2019 & \\
\hline VI1 & 100 & Yellow & 1.20 & Jun 2015 & Jun 2017 & \multirow{3}{*}{$\begin{array}{l}\text { Anemia, depression, fatigue, general } \\
\text { weakness, nervous debility, vitamin } \\
\text { A and C deficiency, weakness of } \\
\text { stomach and liver. }\end{array}$} \\
\hline VI2 & 100 & $"$ & 1.03 & Jul 2015 & Jul 2017 & \\
\hline VI3 & 100 & $"$ & 1.03 & Jan 2016 & Jan 2018 & \\
\hline
\end{tabular}

$\mathrm{DOM}=$ Date of manufacture, $\mathrm{DOE}=$ Date of expiry. 
The presence of aerobic bacteria and spore forming bacteria were observed in all the samples tested in this study (Table 2). However, the bacterial counts varied widely among the brands. The highest aerobic bacterial count was found in CA2 $\left(2.97 \times 10^{5} \mathrm{cfu} / \mathrm{ml}\right)$ and the lowest aerobic bacterial count was found in HE1 $\left(6.20 \times 10^{2} \mathrm{cfu} / \mathrm{ml}\right)$. Presence of high level of aerobic bacteria in herbal medicines was also reported in several studies conducted in different countries (Alwakeel 2008, Khurana et al. 2011, Onyambu et al. 2013). The plants used in the preparation of herbal medicine are rich in organic compounds and minerals which provided the nutrition to the microorganisms associated with the herbal raw material and might have facilitated the multiplication of the microorganisms found in this study. These microbes may lead to the deterioration and variation in composition of the final product which may give rise to inferior quality of herbal products. Use of such substandard herbal medicinal products might not provide the claimed therapeutic benefits (Table 1).

Table 2. Microbial load in various herbal medicines.

\begin{tabular}{cccccc}
\hline $\begin{array}{c}\text { Sample } \\
\text { code }\end{array}$ & $\begin{array}{c}\text { TABC } \\
(\mathrm{cfu} / \mathrm{ml})\end{array}$ & $\begin{array}{c}\text { TCC } \\
(\mathrm{cfu} / \mathrm{ml})\end{array}$ & $\begin{array}{c}\text { TSC } \\
(\mathrm{cfu} / \mathrm{ml})\end{array}$ & $\begin{array}{c}\text { MSFB } \\
(\mathrm{cfu} / \mathrm{ml})\end{array}$ & $\begin{array}{c}\text { TYMC } \\
(\mathrm{cfu} / \mathrm{ml})\end{array}$ \\
\hline AS1 & $1.60 \times 10^{5}$ & $\mathrm{ND}$ & $1.30 \times 10^{3}$ & $2.60 \times 10^{2}$ & $1.10 \times 10^{3}$ \\
AS2 & $3.50 \times 10^{3}$ & ND & ND & $2.20 \times 10^{2}$ & 30 \\
AS3 & $6.90 \times 10^{3}$ & ND & $2.00 \times 10^{2}$ & $3.10 \times 10^{2}$ & 80 \\
BA1 & $1.20 \times 10^{5}$ & ND & $5.00 \times 10^{2}$ & $2.10 \times 10^{2}$ & $1.10 \times 10^{2}$ \\
BA2 & $1.70 \times 10^{3}$ & ND & 40 & $1.40 \times 10^{2}$ & ND \\
BA3 & $6.40 \times 10^{3}$ & ND & $2.40 \times 10^{2}$ & $4.00 \times 10^{2}$ & $2.10 \times 10^{2}$ \\
CA1 & $2.05 \times 10^{4}$ & $2.05 \times 10^{3}$ & $1.85 \times 10^{3}$ & $1.30 \times 10^{2}$ & $5.00 \times 10^{2}$ \\
CA2 & $2.97 \times 10^{5}$ & $2.80 \times 10^{3}$ & $2.30 \times 10^{4}$ & 55 & $1.30 \times 10^{3}$ \\
CA3 & $8.00 \times 10^{3}$ & $7.70 \times 10^{2}$ & 30 & $4.00 \times 10^{2}$ & $1.60 \times 10^{2}$ \\
EN1 & $1.66 \times 10^{4}$ & ND & 50 & 90 & $2.00 \times 10^{2}$ \\
EN2 & $4.60 \times 10^{3}$ & ND & 40 & 90 & $2.80 \times 10^{2}$ \\
EN3 & $7.40 \times 10^{3}$ & ND & $1.00 \times 10^{2}$ & $2.40 \times 10^{2}$ & $\mathrm{ND}$ \\
HE1 & $6.20 \times 10^{2}$ & ND & 30 & $1.90 \times 10^{2}$ & $1.00 \times 10^{2}$ \\
HE2 & $3.10 \times 10^{3}$ & ND & ND & $1.40 \times 10^{2}$ & $1.20 \times 10^{2}$ \\
HE3 & $8.80 \times 10^{3}$ & $3.60 \times 10^{2}$ & $1.90 \times 10^{2}$ & $2.00 \times 10^{2}$ & $\mathrm{ND}$ \\
NA1 & $1.45 \times 10^{5}$ & ND & $1.70 \times 10^{4}$ & $1.40 \times 10^{2}$ & $1.80 \times 10^{4}$ \\
NA2 & $1.86 \times 10^{4}$ & ND & $5.00 \times 10^{1}$ & $2.60 \times 10^{2}$ & 20 \\
NA3 & $8.00 \times 10^{3}$ & ND & 90 & $3.40 \times 10^{2}$ & $2.10 \times 10^{2}$ \\
SA1 & $4.60 \times 10^{3}$ & ND & 40 & 40 & 50 \\
SA2 & $1.04 \times 10^{4}$ & ND & ND & 60 & $1.70 \times 10^{2}$ \\
SA3 & $1.30 \times 10^{4}$ & $6.50 \times 10^{2}$ & $1.50 \times 10^{2}$ & 90 & $1.10 \times 10^{2}$ \\
VI1 & $1.29 \times 10^{4}$ & ND & 30 & $1.00 \times 10^{2}$ & 10 \\
VI2 & $2.70 \times 10^{4}$ & ND & ND & $1.25 \times 10^{2}$ & 20 \\
VI3 & $8.50 \times 10^{3}$ & $8.10 \times 10^{2}$ & $1.30 \times 10^{2}$ & $2.30 \times 10^{2}$ & 10 \\
\hline & & & & 2 & 2 \\
\hline
\end{tabular}

$\mathrm{TABC}=$ Total aerobic bacterial count $\mathrm{TCC}=$ Total coliform count, $\mathrm{TSC}=$ Total staphylococcal count, TYMC = Total yeast-mold count, MSFB = Mesophilic spore forming bacteria, cfu = Colony forming unit, $\mathrm{ml}$ $=$ Milliliter and ND= Not detected. 
The highest coliform bacterial count $\left(2.80 \times 10^{3} \mathrm{cfu} / \mathrm{ml}\right)$ was found in CA2 (Table 2). The water of the manufacturing plant might be the source of this type of bacteria. A moderate positive correlation was observed between TABC and coliform count (Table 3). The presence of Staphylococcus spp. were observed in $20(83.33 \%)$ samples. The highest Staphylococcus spp. were also found in CA2 $\left(2.30 \times 10^{4} \mathrm{cfu} / \mathrm{ml}\right)$. A significant strong positive correlation was observed between TABC and TSC (Table 3). The mesophilic spore forming bacteria was found in all of the samples ranging from 40 to $4.00 \times 10^{2} \mathrm{cfu} / \mathrm{ml}$. The presence of yeast or mold was observed in 21 $(87.5 \%)$ samples. The highest yeast and mold count was found in NA1 $\left(1.80 \times 10^{4} \mathrm{cfu} / \mathrm{ml}\right)$. Presence of high level of yeast and mold in some commercial herbal drugs was also reported by Khurana et al. (2011). Among the fungal isolates, Aspergillus spp., Penicillium spp., Rhizopus spp. and Saccharomyces spp. were predominant.

Table 3. Pearson correlation coefficient (r) among the microbial counts.

\begin{tabular}{llllll}
\hline & TABC & TCC & TSC & MSFB & TYMC \\
\hline TABC & 1 & & & & \\
TCC & $0.5291^{* *}$ & 1 & & & \\
TSC & $0.8488^{* *}$ & $0.5904^{* *}$ & 1 & & \\
MSFB & -0.1897 & -0.1982 & -0.2718 & 1 & \\
TYMC & 0.3914 & -0.037 & $0.6219^{* *}$ & -0.1035 & 1 \\
\hline
\end{tabular}

** Correlation is significant at the $\mathrm{p}<0.01$ level.

A total of 37 bacterial isolates were randomly selected and purified for identification. On the basis of cultural characteristics and biochemical tests, 12 (32.43\%) were identified as Bacillus spp., 7 (18.91\%) were identified as E. coli, 4 (10.81\%) were identified as Klebsiella spp., 4 $(10.81 \%)$ were identified as S. epidermidis, $3(8.10 \%)$ were identified as S. aureus, $3(8.10 \%)$ were identified as Proteus spp., 1 (2.70\%) was identified as E. aerogenes and $3(8.10 \%)$ isolates were unidentified. Bacillus spp. was the most frequently found in these herbal medicinal products because they are widely distributed in the soil, dust and air. Bacteria of this genus produce spores which are resistant to harsh processing, elevated heat and dry conditions. Therefore, they can survive for a long period in the product in a dormant state (Kunene et al. 1999).

In some studied samples $S$. epidermidis and $S$. aureus were found and those might have originated from personnel involved in production process. In a previous study, it was reported that approximately 2300 microorganisms are present per square centimeter of human skin and thus people are generally considered as the major source of contamination of drugs (Yerima et al. 2012). The skin flakes that make up most of the dust act as rafts for these organisms. Since these rafts are very light, they are carried by air current surrounding the personnel involved in formulation, filling and packaging, thus bringing about contamination of the medicinal products. The presence of potentially pathogenic opportunistic microbes, including S. aureus, is a matter of serious concern because they may cause a significant deterioration in the health status of patients, particularly those who are immunocompromised or have an immature immune system. The microbiological data obtained in this study were compared with the acceptance criteria mentioned in well-recognized international monographs or standards (British Pharmacopoeia 2004, WHO 2007). Out of the 24 samples, 5 (20.83\%) did not comply with the acceptance criteria stipulated in British Pharmacopoeia (2004) and WHO (2007) standards. 
Antibiotics are important arsenal to combat with infectious disease causing bacteria. However, widespread misuse of antibiotics in health and poultry sector has made many bacterial species resistant to several antibiotics. Antibiotic susceptibility test was carried out for the 7 selected $E$. coli isolates and 3 selected $S$. aureus isolates after being confirmed by morphological and biochemical tests. The diameters of zone of inhibition produced by the selected antibiotics against each of the isolates are presented in Table 4 . The isolates produced diverse type of zone of inhibition against the antibiotics tested. Antibiotic resistance profile of $E$. coli isolates is presented in Fig.1. The study revealed that all the E. coli isolates (100\%) were resistant to amoxicillin and penicillin G. Out of 7 isolates $6(85.71 \%)$ were resistant to nitrofurantoin while $5(71.43 \%)$ were

Table 4. Zone of inhibition (mm) produced by $E$. coli and $S$. aureus isolates against some selected antibiotics.

\begin{tabular}{lcccccccccc}
\hline \multirow{2}{*}{$\begin{array}{l}\text { Antibiotics } \\
\text { disc potency) }\end{array}$} & \multicolumn{7}{c}{ Zone of inhibition (mm) } \\
\cline { 2 - 11 } & $\mathrm{EC}_{1}$ & $\mathrm{EC}_{2}$ & $\mathrm{EC}_{3}$ & $\mathrm{EC}_{4}$ & $\mathrm{EC}_{5}$ & $\mathrm{EC}_{6}$ & $\mathrm{EC}_{7}$ & $\mathrm{SA}_{1}$ & $\mathrm{SA}_{2}$ & $\mathrm{SA}_{3}$ \\
\hline Amoxicillin $(10 \mu \mathrm{g})$ & 14 & 8 & 7 & 8 & 7 & 21 & 8 & 11 & 17 & 11 \\
Ceftriaxone $(30 \mu \mathrm{g})$ & 45 & 8 & 10 & 10 & 11 & 13 & 23 & 16 & 37 & 42 \\
Cefuroxime $(30 \mu \mathrm{g})$ & 41 & 6 & 6 & 6 & 6 & 6 & 22 & 9 & 29 & 26 \\
Ciprofloxacin $(5 \mu \mathrm{g})$ & 37 & 34 & 28 & 26 & 30 & 33 & 35 & 37 & 30 & 42 \\
Erythromycin $(15 \mu \mathrm{g})$ & 32 & 36 & 37 & 10 & 16 & 21 & 29 & 40 & 34 & 31 \\
Gentamicin $(10 \mu \mathrm{g})$ & 29 & 29 & 30 & 28 & 29 & 36 & 38 & 36 & 32 & 31 \\
Imipenem $(10 \mu \mathrm{g})$ & 52 & 40 & 37 & 36 & 38 & 40 & 29 & 41 & 46 & 55 \\
Nalidixic acid $(30 \mu \mathrm{g})$ & 30 & 25 & 18 & 18 & 23 & 28 & 20 & 20 & 19 & 20 \\
Nitrofurantoin $(300 \mu \mathrm{g})$ & 21 & 22 & 20 & 23 & 22 & 19 & 21 & 25 & 27 & 16 \\
Penicillin $\mathrm{G}(10 \mathrm{units})$ & 11 & 7 & 6 & 6 & 6 & 11 & 7 & 9 & 16 & 12 \\
\hline
\end{tabular}

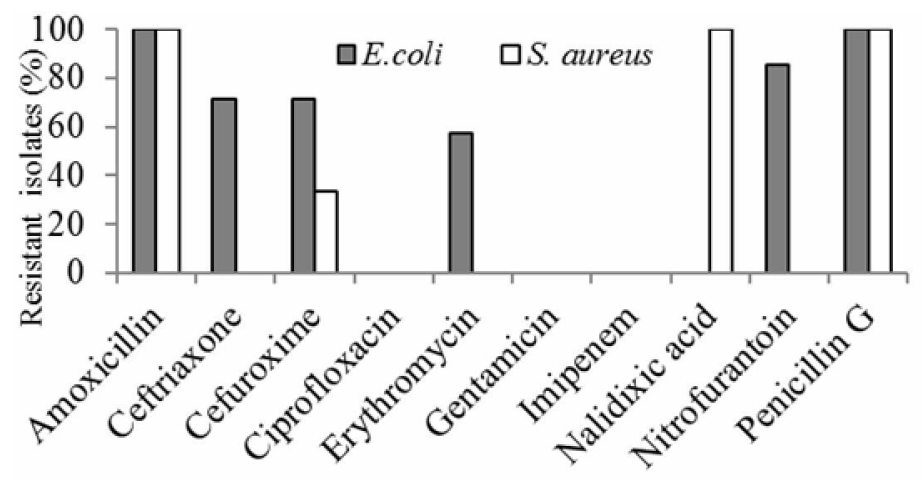

Fig. 1. Antibiotic resistance profile of the E. coli and S. aureus isolates.

resistant to ceftriaxone and cefuroxime. Four isolates (57.14\%) demonstrated resistance to erythromycin. However, ciprofloxacin, gentamicin, imipenem and nalidixic acid were found effective against the E. coli isolates tested (Fig.1). The study showed that all of the S. aureus 
isolates (100\%) were resistant to amoxicillin, nalidixic acid, penicillin G. Only one of the $S$. aureus isolates was resistant to cefuroxime. Esimone et al. (2007) also reported the presence of cefuroxime and nitrofurantoin resistant bacteria in herbal medicine. However, ceftriaxone, ciprofloxacin, erythromycin, gentamicin, imipenem and nitrofurantoin were found effective against $S$. aureus isolates (Fig. 1). The presence of antibiotic-resistant bacteria in herbal medicine is highly objectionable because these bacteria may facilitate the transfer of antibiotic resistant genes. The study revealed that some of the herbal medicinal products contain microorganisms above the acceptable limit stipulated in British Pharmacopoeia (2004) and WHO (2007) guidelines. The presence of large number of microbial contaminants including the antibiotic resistant bacteria in some herbal samples may reduce or destroy the therapeutic potential of the medicinal product and may also cause the onset of another disease to the patient. The manufacturers of herbal products must properly follow current good manufacturing practice to ensure the microbial quality and safety of the herbal medicinal products.

\section{Acknowledgement}

The authors are grateful to the authority of the Jahangirnagar University for financial support.

\section{References}

Ali N, Hashim NH, Saad B, Safan K, Nakajima M and Yoshizawa T 2005. Evaluation of a method to determine the natural occurrence of aflatoxins in commercial traditional herbal medicines from Malaysia and Indonesia. Food Chem. Toxicol. 43: 1763-1772.

Alwakeel SS 2008. Microbial and heavy metals contamination of herbal medicines. Res. J. Microbiol. 3: 683-691.

Barnes J, Anderson LA and Phillipson JD 2007. Herbal Medicines. Pharmaceutical Press, London, UK. pp. 4-5.

Bauer AW, Kirby WM, Sherris JC and Turck M 1966. Antibiotic susceptibility testing by a standardized single disk method. Am. J. Clin. Pathol. 45: 493-496

British Pharmacopoeia 2004. Appendix XVI (A-D). British Pharmacopoeia. Comission, TSO, London. pp. 331-351

Brooks GF, Caroll KC, Butel JS and Morse SA 2007. Jawetz, Melnick and Adelberg's Medical Microbiology. $24^{\text {th }}$ ed, The McGraw-Hill Co. New York, pp. 224-230.

Cappuccino JG and Sherman N 1996. Microbiology: A Laboratory Manual, 4th ed. The Benjamin Cummings Publishing Co. California. pp. 13-182

CLSI 2006. Performance standards for antimicrobial disk susceptibility tests: approved standard- $9^{\text {th }}$ ed. Clinical and Laboratory Standards Institute, document M2-A9, 26:1-37.

Esimone CO, Oleghe PO, Ibezim EC, Okeh CO and Iroha IR 2007. Susceptibility resistance profile of microorganisms isolated from herbal medicine products sold in Nigeria. Afr. J. Biotechnol. 6: 2766-2775.

Finegold SM and Martin WJ 1982. Bailey and Scott's Diagnostic Microbiology, Sixth ed. The C. V. Mosby Co. Missouri. pp. 158-387.

Govender S, Du Plessis-Stoman D, Downing T and van de Venter M 2006. Traditional herbal medicines: Microbial contamination, consumer safety and the need for standards. South African J. Sci. 102: 253255.

Khurana N, Sharma RK and Bhaduria S 2011. Microbiological quality assessment of some commercial herbal drugs. Int. J. Pharm. Qual. Assur. 2: 76-78.

Kunene NF, Hastings JW and von Holy A 1999. Bacterial populations associated with a sorghum-based fermented weaning cereal. Int. J. Food Microbiol. 49: 75-83.

Lopamudra and Kuila RK 2005. Incidence of different types of sporeforming bacteria in pasteurised market milk supplies. J. Dairying Foods \& H. S. 24 (1): 20-23. 
Mugoyela V and Mwambete KD 2010. Microbial contamination of nonsterile pharmaceuticals in public hospital settings. Therapeutics Clin. Risk Manag. 6: 443-448.

Okunlola A, Adewoyin BA and Odeku OA 2007. Evaluation of pharmaceutical and microbial qualities of some herbal medicinal products in south western Nigeria. Trop. J. Pharm. Res. 6: 661-670.

Onyambu MO, Chepkwony HK, Thoithi GN, Ouya GO and Osanjo GO 2013. Microbial quality of unregulated herbal medicinal products in Kenya. Afr. J. Pharmacol. Therapeut. 2: 70-75.

Sharafati-chaleshtori R, Sharafati-chaleshtori F and Rafieian M 2011. Biological characterization of Iranian walnut (Juglans regia) leaves. Turk. J. Biol. 35: 635-639.

Shoeb, M, Nahar N, Ahmed F, Mosihuzzaman M and Nahar N 2011. Studies on locally available three antidiabetic herbal medicine. Bangladesh J. Pharmacol. 6: 124-127.

Silbergeld EK, Graham J and Price LB 2008. Industrial food production, antimicrobial resistance, and human health. Annu. Rev. Public Health. 29: 151-169.

WHO 2000. General guidelines for methodologies on research and evaluation of traditional medicines. Annex II, Research guidelines for evaluating the safety and efficacy of herbal medicines. World Health Organization, Geneva. pp. 27.

WHO 2007. WHO guidelines for assessing quality of herbal medicines with reference to contaminants and residues. World Health Organization, Geneva. pp. 27-28.

WHO 2014. Antimicrobial resistance: Global report on surveillance. World Health Organization, Geneva. pp. XIX.

Wilt TJ, Ishani A, Rutks I and MacDonald R 2000. Phytotherapy for benign prostatic hyperplasia. Public Health Nutri. 3: 459-472.

Yerima MB, Jodi SM, Farouq AA, Ya'u B, Junaidu AU, Al-Mustapha MN, Ahmed JM and Shinkafi AL 2012. Microbiological quality of some expired drugs in Sokoto Metropolis, Nigeria. Nig. J. Basic Appl. Sci. 20:142-145.

(Manuscript received on 11 August, 2018; revised on 25 December, 2018) 